\title{
Immunoglobulin G4-Related Disease of the Maxillofacial Region. A Rare Case
}

\author{
Enfermedad Relacionada con Inmunoglobulina G4 en el Área Maxilofacial. Un Caso Raro
}

Vitor José Fonseca ${ }^{1}$; Afonso Celso Manzano de Moraes ${ }^{1}$; Sergio Olate ${ }^{2}$;uciana Asprino ${ }^{1}$ \& Márcio de Moraes ${ }^{1}$

FONSECA, V. J.; MANZANO DE MORAES, A. C.; OLATE, S.; ASPRINO, L. \& DE MORAES, M. Immunoglobulin G4-Related disease of the maxillofacial region. A Rare Case. Int. J. Morphol., 36(4):1509-1513, 2018.

SUMMARY: IgG4-related disease is a systemic, multifocal, immune-mediated disorder that can affect multiple organs and may present as a tumor, with rare cases described in the maxillofacial region. A female patient, 53 years old, presenting tumor-like mass in the right mandibular region. Magnetic resonance imaging suggested well circumscribed nodular lesion adjacent to the branch / body of the mandible, extending posteriorly to the masseter muscle. During the surgical procedure of excision, a lesion was observed adhering to the right masseter muscle, but it was possible to remove it completely. Histopathological and immunehistochemical analysis suggested diagnosis of IgG4-related disease, furthermore, IgG4 serum count was increased. Actually, the patient continues on periodical followups in our service and by other specialties. Can be concluded that precise diagnosis of this pathology depends on many factors, being challenging and the treatment involves multidisciplinary evaluation due to the possibility of involvement of several other organs.

KEY WORDS: IgG4; IgG4-related disease; Tumor

\section{INTRODUCTION}

Immunoglobulin IgG4-related disease is a multifocal systemic immune-mediated disorder characterized by a fibrosclerotic inflammatory pattern, which may affect multiple organs (Stone et al., 2012), most commonly presenting as a tumor or "masslike", and in smaller number, presenting infiltrative characteristic (Thompson \& Whyte, 2018).

According to Brito-Zerón et al. (2014) reported in the literature the involvement of several organs, mainly including the pancreas, salivary and lacrimal glands, lungs, among others. The involvement of the salivary glands or sialadenitis related to IgG4 disease are the most prevalent presentations in the head and neck region, and because of this, are well described in the literature. On the other hand, few reports have been well documented in the maxillofacial area.

The present study aims to report a rare case of a patient with an increase in volume in the mandibular region of the right side, whose diagnosis, after histopathology and immunohistochemistry, revealed IgG4 immunoglobulinrelated disease. We also sought to discuss the pathophysiological factors.

\section{CASE REPORT}

A 53-year-old female patient, leucoderma, reporting previous medical history of controlled systemic arterial hypertension, attended our Service complaining about of volume increase in face. Clinical examination revealed a solid mass located in the right mandibular region, painful during manipulation. Simultaneously palpation extraoral and intraoral, suggested a lesion well adhered to the tissues, cervical lymphadenopathies were not evidenced. Panoramic radiographic image did not suggest significant bone alterations. Ultrasonographic study of the salivary glands also did not show abnormalities. Magnetic resonance imaging suggested a well circumscribed nodular lesion adjacent to the mandible ramus/ body, extending posteriorly to the masseter muscle, with no separation between these structures (Figs. 1A-B).

A ultrasound-guided fine-needle aspiration biopsy was performed and the result was inconclusive, suggesting a chronic inflammatory process. Due to this nonspecific result, an excisional biopsy of the lesion was performed under local anesthesia by intraoral access. During the blunt dissection, although the lesion was well adhered to the masseter muscle, it was possible to detach it completely (Fig. 2).

\footnotetext{
${ }^{1}$ Department of Oral and Maxillofacial Surgery, Piracicaba Dental School, State University of Campinas, Piracicaba (SP), Brazil.

${ }^{2}$ Division of Oral, Facial and Maxillofacial Surgery. Center of Excellence in Morphological and Surgical Studies (CEMyQ), Universidad de La Frontera, Temuco, Chile.
} 


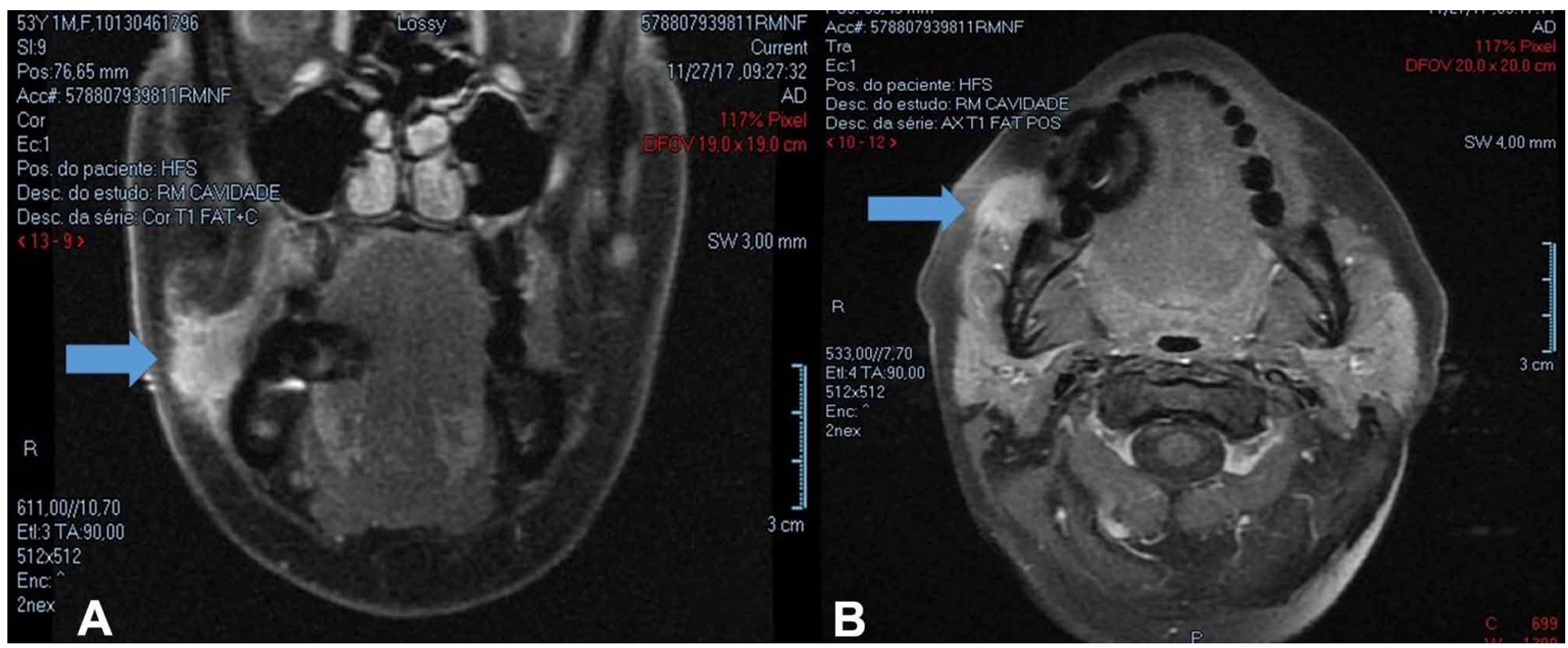

Fig. 1. Magnetic resonance imaging: coronal (A) and axial (B) planes showing the position and dimensions of the lesion.

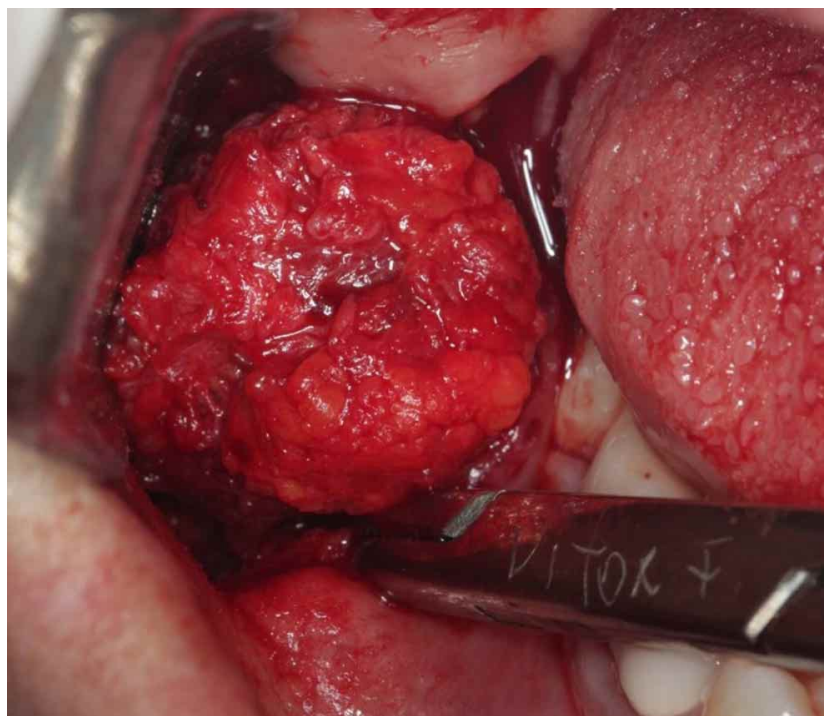

Fig. 2. Removal of the lesion through intraoral access.

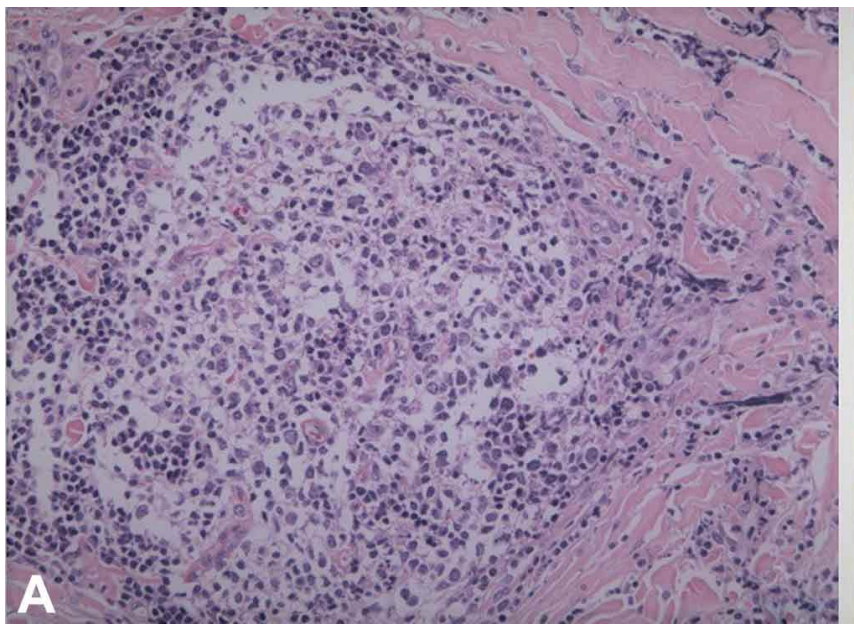

Histological examination of a piece measuring $2.2 \mathrm{x}$ $1.8 \times 1.4 \mathrm{~cm}$, suggested a non-specific chronic inflammatory process, rich in plasma cells, with sclerotic infiltration (Figs. 3A-B), suggesting the accomplishment of immunohistochemistry due to the possibility of related disease to IgG4 / inflammatory pseudotumor. The immunehistochemical study showed a mixed lymphoid population with CD20 expression in B lymphocytes and CD3 lymphocytes in the T lymphocytes. Among the plasma cells, $\mathrm{IgG} 4+/ \mathrm{IgG}+$ ratio of $40 \%$ was observed, suggesting a diagnosis of IgG4 related disease (Figs. 4A-B).

After anatomopathological and immunohistochemical examinations, we requested several laboratory tests, which showed an increase in the IgG4 serum count. The other Creactive protein, hemogram and leukogram tests were counted within the reference values.

Fig. 3. A, (HE) Histological slide image (20x magnification) showing non-specific chronic inflammatory process. B, (HE) Histological slide image (40x magnification) with inflammatory infiltrate rich in plasma cells (arrow) with sclerotic infiltration. 

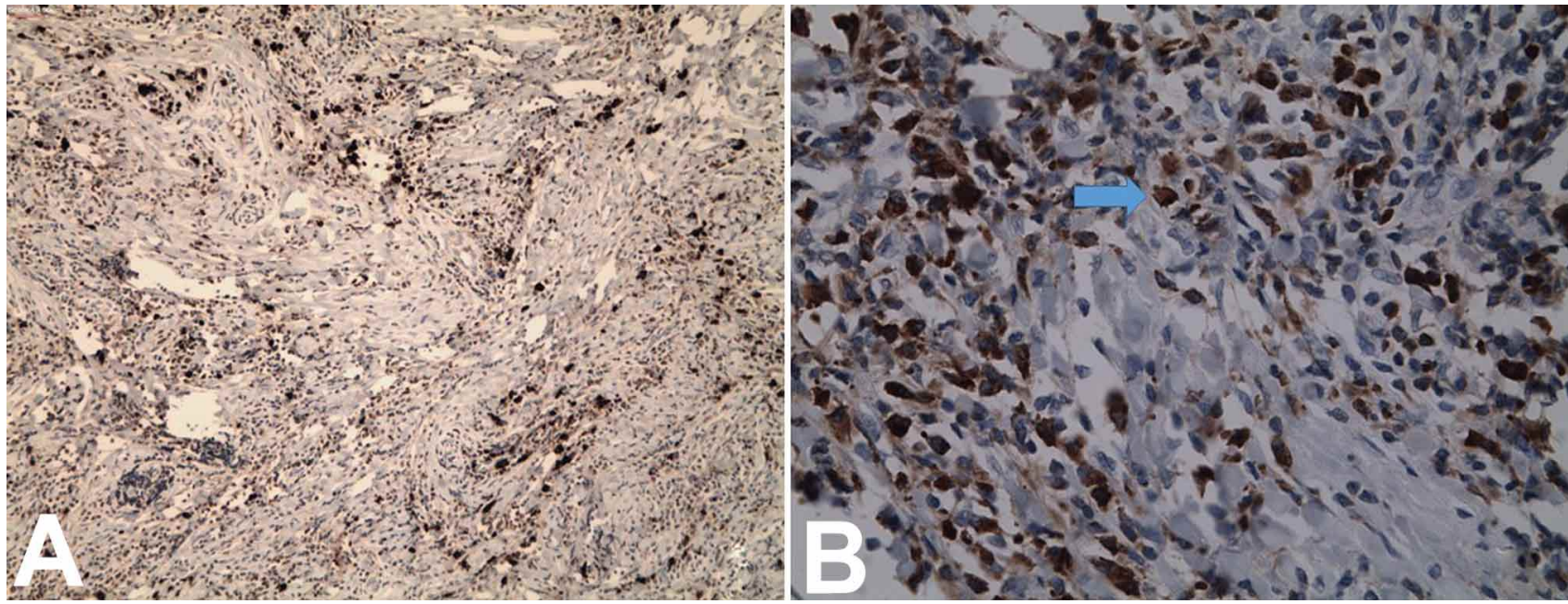

Fig. 4. A, Image of immunohistochemical (10x magnification) showing a mixed lymphoid population. B, Image of immunohistochemical (40x magnification) showing that among the plasma cells, IgG4 + (arrow) / IgG + ratio of $40 \%$ was observed, suggesting a diagnosis of IgG4 related disease.

The patient is in follow-up with no complaints, showing a good evolution with a decrease in volume face. She was referred to the Head and Neck and Rheumatology Surgery Service to follow up on other possible changes related to the disease. No other disease-related changes have been found so far.

\section{DISCUSSION}

The pathogenesis of the disease is still poorly understood, with autoimmune and infectious agents being considered as potential immunological triggers (Stone et al.). Genetic studies to date have not been enlightening (Umehara et al., 2012). Some authors believe that it is a Helper T-cell mediated immune response of type 2 (Th2), followed by activation of regulatory $\mathrm{T}$ cells (Treg), which leads to increased expression of interleukins, mainly 4, 5, 10, 13, and transforming growth factor beta (TGF-b) (Stone et al.; Umehara et al.; Deshpande et al., 2012).

These cytokines stimulate the production of IgG4 and, to a lesser extent, production of $\mathrm{IgE}$, eosinophilia and the progression of fibrosis, which are the characteristics of the diseases (Palazzo et al., 2014). It is not possible to say whether these deposits, mainly of IgG4, are involved in immunocomplex mediated tissue damage or if they are only secondary phenomena, that is, without causal relation (Stone et al.; Palazzo et al.). Due to unstable bonds between their heavy chains, IgG4 undergoes random recombination, also called FAB-arm exchange (Stone et al.), giving this class of antibodies unique characteristics. Due to the recombination event, bispecific molecules are formed that lose the ability to crosslink with antigens, not forming immune complexes (Guma \& Firestein, 2012). Thus, IgG4 does not effectively activate the classical complement pathway and traditionally has been assigned only a limited role in immune activation (Stone et al.).

According to Palazzo et al., the diagnosis should be based on clinical aspects: volume or mass increases in one or more organs, laboratory tests include serum IgG4 count greater than $1.35 \mathrm{~g} / \mathrm{L}$, and pathological criteria: marked infiltration by lymphocytes and plasma cells, more than 10 IgG4 positive plasma cells per high power field with IgG4 / $\mathrm{IgG}$ ratio greater than $40 \%$ and sclerotic infiltration. In the case reported, it is possible to observe an increase in volume, firmness of the palpation, and an increased IgG4 count, and in anatomopathological and immunohistochemical examination, a non-specific chronic inflammatory process was found, rich in plasma cells, with stromal sclerosis (Figs. 3A-B), with a mixed lymphoid population, expression for $\mathrm{CD} 20$ on B lymphocytes and CD3 on T lymphocytes, and $\mathrm{IgG} 4+/ \mathrm{IgG}+$ ratio of $40 \%$ (Figs. 4A-B) characterizing sufficient criteria to determine IgG4 related disease.

Increased $\mathrm{IgG} 4$ concentrations in tissues and plasma may be useful in the diagnosis of DR-IgG4, but neither is a disease-specific marker (Stone et al.). According to Guma \& Firestein, many patients have increased serum IgG4 levels, but approximately $40 \%$ have normal plasma concentrations, even with classic histopathological findings of the disease.

In addition to the IgG4 count, other tests may show changes, such as slightly elevated C-reactive protein, 
elevated erythrocyte sedimentation rate, anemia, thrombocytosis, peripheral eosinophilia, and elevated IgE serology (Della Torre et al., 2014; Culver et al., 2017). However, according to the Andrew et al. (2014), the erythrocyte sedimentation rate and C-reactive protein are typically normal. In the reported clinical case, only an increase in IgG4 count was observed and other tests within the normality patterns. In the reported clinical case, only an increase in IgG4 count was observed and other tests within the normality patterns.

The epidemiology of the disease remains poorly understood due to the recent recognition of the lesion and the absence of studies (Vasaitis, 2016). Yamamoto et al. (2014) reports the disease predominantly affects male patients, with the possible exception of involvement in the head and neck region, where the gender distribution is very close. The mean age at onset of symptoms appears to be between 50 and 60 years, consistent with the age of our patient (Yamamoto et al.; Wallace et al., 2015), but some patients may present with younger symptoms and may even affect children (Mannion \& Cron, 2011).

As in the reported clinical case, the main signs of the disease are the appearance of nodules and masses, focal or diffuse, which are usually discovered through physical or radiological examination. In the early stages, the disease is asymptomatic in most cases. The evolution of the disease can lead to pain complaints due to tissue compression. The patient in the study reported painful symptomatology on palpation. Atopic dermatitis, asthma or chronic sinusitis can be observed in up to $40 \%$ of patients; however, pancreatitis is the most common clinical pathology and is often accompanied by involvement of the bile duct. Other clinical manifestations may occur such as the involvement of the abdominal or mediastinal lymph nodes (80\% of cases), salivary or lacrimal glands (40\%), kidneys (30\%), lungs $(13 \%)$ and retroperitoneum (10\%) (Palazzo et al.). In view of the variability of systemic implications, we referred the patient for evaluation with other specialties, such as head and neck surgery and rheumatology, with no other alterations so far.

There are still no definitive strategies for the treatment of IgG4-RD. But there are some guidelines that were suggested in 2015. Of these, it is advised, in asymptomatic patients with limited disease, for example, with only involvement of the lymph nodes or salivary glands, "observe and wait", keeping the patients closely monitored. In symptomatic patients, interventions are indicated, either through glucocorticoids and B-cell depletion to induce remission of symptoms, or through surgical interventions (Khosroshahi et al., 2015).
Due to the increase in volume, promoting aesthetic dissatisfaction and painful complaints in the patient, the surgical procedure was chosen for excision of the lesion under local anesthesia (Fig. 2). As reported by Gutiérrez Santamaría et al. (2014), at least a reasonable-sized biopsy has to be obtained to secure the diagnosis and to rule out other pathologies. This is a systemic disease, and the patients require work-up and follow-up for the presence of additional sites of involvement. At the moment, the patient is without symptoms, being followed up by our Service and other specialties.

It is observed that the precise diagnosis depends on many factors being challenging, as described above, and the treatment involves the multidisciplinary evaluation due to the possibility of involvement of several other organs, being, therefore, the knowledge by the maxillofacial and head and neck surgeons for correct conduction of the disease in a systemic way.

FONSECA, V. J.; MANZANO DE MORAES, A. C.; OLATE, S.; ASPRINO, L. \& DE MORAES, M. Enfermedad Relacionada con Inmunoglobulina G4 en el Área Maxilofacial. Un Caso Raro. Int. J. Morphol., 36(4):1509-1513, 2018.

RESUMEN: La enfermedad relacionada con IgG4 es una condición sistémica, multifocal, mediada por una alteración de la respuesta inmune que puede afectar diferentes órganos o puede presentarse como un tumor, raramente descrito en el área maxilofacial. Se describe el caso de una paciente de sexo femenino de 53 años de edad, presentando una masa tumoral en el ángulo mandibular derecho. La resonancia magnética sugirió un área nodular bien delimitada adyacente al cuerpo mandibular y extendida posteriormente hasta el musculo masetero. Durante la escisión quirúrgica, la lesión se presentaba adherida al musculo de forma lateral siendo posible el retiro total de la lesión. El estudio histopatológico e inmunohistoquimico determinó el diagnóstico de enfermedad relacionada con IgG4 presentando un conteo de igG4 aumentado. Actualmente, la paciente continua con seguimiento por la especialidad. Se puede concluir que el diagnóstico preciso de esta patología depende de algunos factores; el tratamiento debe ser multidsciplinario debido a la inclusión de diferentes órganos en la enfermedad.

PALABRAS CLAVE: IgG4; Enfermedad relacionada con IgG4-related disease; Tumor

\section{REFERENCES}

Andrew, N.; Kearney, D.; Sladden, N.; Goss, A. \& Selva, D. Immunoglobulin G4-related disease of the hard palate. J. Oral Maxillofac. Surg., 72(4):71723, 2014.

Brito-Zerón, P.; Ramos-Casals, M.; Bosch, X. \& Stone, J. H. The clinical spectrum of IgG4-related disease. Autoimmun. Rev., 13(12):1203-10, 2014. 
FONSECA, V. J.; MANZANO DE MORAES, A. C.; OLATE, S.; ASPRINO, L. \& DE MORAES, M. Immunoglobulin G4-Related disease of the maxillofacial region. A Rare Case. Int. J. Morphol., 36(4):1509-1513, 2018.

Culver, E. L.; Sadler, R.; Bateman, A. C.; Makuch, M.; Cargill, T.; Ferry, B.; Aalberse, R.; Barnes, E. \& Rispens, T. Increases in IgE, eosinophils, and mast cells can be used in diagnosis and to predict relapse of IgG4related disease. Clin. Gastroenterol. Hepatol., 15(9):1444-52, 2017.

Della Torre, E.; Mattoo, H.; Mahajan, V. S.; Carruthers, M.; Pillai, S. \& Stone, J. H. Prevalence of atopy, eosinophilia, and $\operatorname{IgE}$ elevation in IgG4-related disease. Allergy, 69(2):269-72, 2014

Deshpande, V.; Zen, Y.; Chan, J. K.; Yi, E. E.; Sato, Y.; Yoshino, T.; Klöppel, G.; Heathcote, J. G.; Khosroshahi, A.; Ferry, J. A.; Aalberse, R. C.; Bloch, D. B.; Brugge, W. R.; Bateman, A. C.; Carruthers, M. N.; Chari, S. T.; Cheuk, W.; Cornell, L. D.; Fernandez-Del Castillo, C.; Forcione, D. G.; Hamilos, D. L.; Kamisawa, T.; Kasashima, S.; Kawa, S.; Kawano, M.; Lauwers, G. Y.; Masaki, Y.; Nakanuma, Y.; Notohara, K.; Okazaki, K.; Ryu, J. K.; Saeki, T.; Sahani, D. V.; Smyrk, T. C.; Stone, J. R.; Takahira, M.; Webster, G. J.; Yamamoto, M.; Zamboni, G.; Umehara, H. \& Stone, J. H. Consensus statement on the pathology of IgG4-related disease. Mod. Pathol., 25(9):1181-92, 2012.

Guma, M. \& Firestein, G. S. IgG4-related diseases. Best Pract. Res. Clin. Rheumatol., 26(4):425-38, 2012.

Gutiérrez Santamaría, J.; Romagosa Pérez-Portabella, C.; Mogedas Vegara, A.; Bordonaba Leiva, S.; Masiá Gridilla, J.; Pamias Romero, J. \& Bescós Atín, C. Locally destructive mandibular pseudotumor as a manifestation of immunoglobulin G4-related disease. Oral Surg. Oral Med. Oral Pathol. Oral Radiol., 118(2):e40-3, 2014.

Khosroshahi, A.; Wallace, Z. S.; Crowe, J. L, Akamizu, T.; Azumi, A.; Carruthers, M. N.; Chari, S. T.; Della-Torre, E.; Frulloni, L.; Goto, H.; Hart, P. A.; Kamisawa, T.; Kawa, S.; Kawano, M.; Kim, M. H.; Kodama, Y.; Kubota, K.; Lerch, M. M.; Löhr, M.; Masaki, Y.; Matsui, S.; Mimori, T.; Nakamura, S.; Nakazawa, T.; Ohara, H.; Okazaki, K.; Ryu, J. H.; Saeki, T.; Schleinitz, N.; Shimatsu, A.; Shimosegawa, T.; Takahashi, H.; Takahira, M.; Tanaka, A.; Topazian, M.; Umehara, H.; Webster, G. J.; Witzig, T. E.; Yamamoto, M.; Zhang, W.; Chiba, T.; Stone, J. H. \& Second International Symposium on IgG4-Related Disease. International Consensus Guidance Statement on the Management and Treatment of IgG4-Related Disease. Arthritis Rheumatol., 67(7):168899, 2015.

Mannion, M. \& Cron, R. Q. Successful treatment of pediatric IgG4 related systemic disease with mycophenolate mofetil: case report and a review of the pediatric autoimmune pancreatitis literature. Pediatr. Rheumatol. Online J., 9(1):1, 2011

Palazzo, E.; Palazzo, C. \& Palazzo, M. IgG4-related disease. Joint Bone Spine, 81(1):27-31, 2014.

Stone, J. H.; Zen, Y. \& Deshpande, V. IgG4-related disease. N. Engl. J. Med., 366(6):539-51, 2012.

Thompson, A. \& Whyte, A. Imaging of IgG4-related disease of the head and neck. Clin. Radiol., 73(1):106-20, 2018.

Umehara, H.; Okazaki, K.; Masaki, Y.; Kawano, M.; Yamamoto, M.; Saeki, T.; Matsui, S.; Sumida, T.; Mimori, T.; Tanaka, Y.; Tsubota, K.; Yoshino, T.; Kawa, S.; Suzuki, R.; Takegami, T.; Tomosugi, N.; Kurose, N.; Ishigaki, Y.; Azumi, A.; Kojima, M.; Nakamura, S.; Inoue, D. \& Research Program for Intractable Disease by Ministry of Health, Labor and Welfare (MHLW) Japan G4 team. A novel clinical entity, IgG4related disease (IgG4RD): general concept and details. Mod. Rheumatol., 22(1):1-14, 2012.

Vasaitis, L. IgG4-related disease: A relatively new concept for clinicians. Eur. J. Intern. Med., 27:1-9, 2016.

Wallace, Z. S.; Deshpande, V.; Mattoo, H.; Mahajan, V. S.; Kulikova, M.; Pillai, S. \& Stone, J. H. IgG4-related disease: clinical and laboratory features in one hundred twenty-five patients. Arthritis Rheumatol., 67(9):2466-75, 2015.

Yamamoto, M.; Takahashi, H. \& Shinomura, Y. Mechanisms and assessment of IgG4-related disease: lessons for the rheumatologist. Nat. Rev. Rheumatol., 10(3):148-59, 2014.

\author{
Corresponding author: \\ Vitor José Fonseca \\ School of Dentistry \\ Dental School of Piracicaba, UNICAMP \\ Avenida Limeira 901 \\ Piracicaba, São Paulo \\ BRAZIL
}

Email: vjfonseca_@hotmail.com

Received: 20-08-2018

Accepted: $13-10-2018$ 